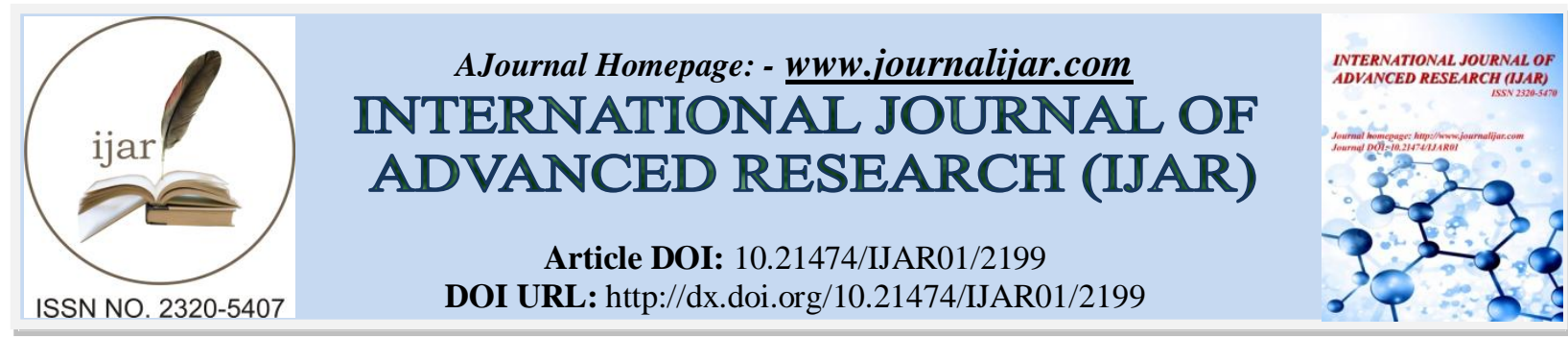

RESEARCH ARTICLE

\title{
CONFLICT MANAGEMENT AND PERFORMANCE OF SELECTED TERTIARY INSTITUTIONS IN ENUGU STATE, NIGERIA.
}

\author{
Dr. Obianuju Mary Chiekezie, Dr. Emmanuel Chijioke Dibua and Anzor Edith Chima.
}

Nnamdi azikiwe university Nigeria.

\section{Manuscript Info}

\section{Manuscript History}

Received: 28 September 2016

Final Accepted: 30 October 2016

Published: November 2016

Key words:-

Conflict Management, Arbitration,

Dialogue, Academic Proficiency,

Incessant Closure, Tertiary Institutions.

\begin{abstract}
The study explored the relationship between conflict management and performance of some selected tertiary institutions in Enugu State, Nigeria. The specific objectives were to find out the extent to which arbitration enhances academic proficiency, and to ascertain how dialogue can reduce incessant closure of selected tertiary institutions in Enugu state. The study employed survey research design. Primary and secondary sources of data were used for this study. Pearson's product moment correlation was used to test the hypotheses. Findings revealed that effective conflict management has significant influence on performance of tertiary institutions in Enugu State, Nigeria. The study concluded that effective conflict management is a necessity for optimal performance of tertiary institutions in Enugu state, Nigeria. Based on the conclusion, it was recommended that tertiary institutions should employ techniques such as; arbitration and dialogue, proper use of authority, observance of rules and regulations, proper structuring of institutions, provision of adequate communication networks and encouraging meaningful participation of stakeholders in resolving conflicts. Again, courses that boarder on peace and rule of law should be introduce in Nigerian tertiary institutions as a University General Studies (GS).
\end{abstract}

Copy Right, IJAR, 2016,. All rights reserved.

\section{Introduction:-}

BACKGROUND OF THE STUDY:-

Human beings are by nature social animals that interact, feel, learn, work and relate with each other in an organisation. They are the most valuable resource as well as the source of most problems and conflicts in organisations. Conflicts can be challenging and dysfunctional. It is inevitable due to the complex and unique qualities people bring to the organisation. Inability to satisfy needs, interest or goals can result to conflict depending on personalities, choices, decisions, behaviours and understanding of others. Conflict is a recurring decimal in all human relationships, be it in the family, institutions, organisations, (Uchendu, Anijaobi, and Odigwe, 2013). Fadipe (2000) sees conflict as a form of disagreement in an establishment between two individuals or groups who have cause to interact formally or informally. It is basically a disagreement between two or more individuals or groups over compatible goals. Conflict therefore involves behaviours that can mean interference or disruption by one person or group of persons in a manner that make the other party less likely to be effective. Conflict means that people are working against each other, in such a manner that what one wants is incompatible with that which another wants. It could bring about competition in the pursuit of goals (Deutsch ,1973) . 
The university as an institution is made up of people with varying needs, interests, choices, features, goals and personalities with different purposes and expectations from the university. They include, students, academic and non academic staff, management team, unions and other stakeholders. Individual differences among people working in an organisation often result to conflicts which might be counter-productive and can give rise to inefficiency, ineffectiveness and in some cases, closure of the organisation. The goal of university education is pursued through its main functions and activities of teaching, research, dissemination of existing and new information, service to the community, and a storehouse of knowledge,(Ferdinand,1981). Carrying out these functions give rise to conflicts within and among different categories of people in the university community. The non-academics who perform support- function may feel unappreciated or even relegated by academic staff. Management often clash with students, staff and other stakeholders in carrying out their functions of recruitment, admission, examination and in the provision of welfare services to the staff and students. Again, the academics have a complex dual role of teaching and conducting research. This dual role could be a source of much tension over the individual's division of time, energy and commitment. The students' purposes are perhaps the most complex of all. As a heterogeneous group, they have conflict within each of them, yet they have to conform to learning certain things in order to acquire a degree (Alabi, 2010).

Given that conflict is inevitable in any organisation, tertiary institution is not an exception. It becomes disturbing when there are no clear measures to employ in management of conflicts in some tertiary institutions to maximize positive effects while minimizing the negative effects. This is important because, poor management of conflict in tertiary institutions will most likely result to ineffectiveness and inefficiency especially in the areas of academic proficiency and incessant closure of these institutions. Educational sub-sector in Nigeria and Enugu State in particular, has been recording series of industrial unrests in the recent past. The effect of repeated and abrupt closure of tertiary institutions due to conflict can better be imagined.

The University of Nigeria, Nsukka, Enugu State University of Science and Technology and Institute of Management and Technology (IMT) Enugu which are the major tertiary institutions in the State have probably not advanced as expected due to unhealthy and poorly managed conflicts. Some of these setbacks may be caused by mismanagement of the University politics, absence of conflict management mechanisms such as dialogue and arbitration, rivalry between competing interest groups or individuals for power, authority and leadership. Consequently, educational standard tend to be questionable in some of these institutions. In some cases, academic calendar has been disrupted, with some academic sessions out rightly lost. Students' academic proficiency has taken a nose dive, while various forms of examination malpractices are on the increase. The situation is worrisome as the public now accuses the tertiary institutions (ivory towers) of turning out graduates that are ill-equipped in character and learning to contribute to the growth and development of the nation.

In view of the above problems, this study becomes imperative as it intends to explore the influence of effective conflict management on the performance of selected tertiary institutions in Enugu state. It focuses on investigating arbitration and dialogue as a conflict management mechanism for organisational optimal performance.

ObJective Of The STUdY:-

The broad objective of this study is to explore the relationship between conflict management and performance of selected tertiary institutions in Enugu state, Nigeria. The specific objectives are to:

i. Examine the extent to which management arbitration enhances academic proficiency in selected tertiary institutions in Enugu state, Nigeria.

ii. Ascertain the extent dialogue can reduce incessant closure of selected tertiary institutions in Enugu state, Nigeria.

\section{RESEARCH QUESTIONS.}

1. To what extent does management arbitration enhances academic proficiency in selected tertiary institutions in Enugu state, Nigeria?

2. To what extent does dialogue reduces incessant closure of selected tertiary institutions in Enugu state, Nigeria?

\section{HYPOTHESIS:-}

The following hypotheses were formulated in line with the objectives:

Ho: Conflict management by arbitration has no significant positive relationship with academic proficiency of selected tertiary institutions in Enugu state, Nigeria. 
Hi: Conflict management by arbitration has a significant positive relationship with academic proficiency of selected tertiary institutions in Enugu state Nigeria.

Ho: Dialogue has no significant positive relationship with incessant closure of selected tertiary institutions in Enugu state Nigeria.

Hi: Dialogue has significant positve relationship with incessant closure of selected tertiary institutions in Enugu state Nigeria.

\section{Review Of Related Literature:- \\ CONCEPTUAL REVIEW:-}

CONFLICT MANAGEMENT:-

Tertiary institutions are always in crises when conflicts occur, which vary from campus to campus depending on the size, location, student population, mission, management and unionization. What can trigger conflict, even large scale ones, in one campus may not in another. Aguba (2009), referred to conflict as a struggle or contest, when workers and management have incompatible, conflicting or irreconcilable views on issues that could lead to conflict. He maintained that it is unthinkable to find any industrial society without industrial conflict, stressing that even Japan which is regarded as the Mecca of industrial harmony has elements of industrial conflict in one form or the other. Ezegbe (1977), defines conflict as "mutual hostility in inter human relations in educational institutions in Nigeria". Mutual hostility can occur in form of black Mailing, withdrawal of love and support, withdrawal of resources, salaries, wages, fringe benefits, or incentive, sudden transfer, suspension, violent demonstration and many more.

Conflict can occur at the level of interpersonal, inter group, organisation or intra-organisational relationship involving chief Executive (Vice chancellors, provost or rector) and the rest of the staff, students, super-ordinate cadre, subordinates, the senior and the junior staff, the student and school authority, the community and the institution. Many people view conflict as an activity that is almost totally negative and has no redeeming qualities while other school of thought accept it as dysfunctional, destructive and at the same times accept it as a catalyst for change, creativity and production (Posisha and Ogbuvwa, 2009).

Alabi, (2010) sees conflict as opposition to another or each other, or disagreement. Kesterner and Ray (2002) see conflict as when two parties (individuals, group, State) are involved and strived for goals which can only be reached by one party, and/or want to employ incompatible means to achieve a certain goal. It thus implies struggle over values or claims to status, power and scarce resources in which the aims of the groups or individual involved are not only to obtain the desired values but neutralize, injure or eliminate rivals. Gilhin (2004) affirms that conflict is a normal part of man's social relations.

Albert (2001) observes that there are productive and destructive conflicts. In his view, a conflict is said to be positive when it is constructively discussed by the parties in amicable terms and settlement reached. Constructively managed conflict induces a positive performance while poorly managed conflict is unhealthy and can lead to destruction. Conflict should not always be seen as something undesirable but rather as a necessary outcome that can bring about positive consequences. Analysis of conflict in tertiary institutions shows that conflict can affect the attainment of institutional goal positively or adversely. Conflict in some cases could facilitate co-operation, foster goal attainment if properly handled. On the other hand, if not well managed, could lead to loss of lives, destruction of properties and disruption of normal academic activities. The survival of any institution therefore, largely depends upon the development of better means of resolving conflicts (Aja, 2012).

\section{Conflict management through dialogue:-}

Conflict managers use the term "dialogue" in a variety of ways. Most dialogue processes involve people sitting down together with a facilitator who will help them explore their feelings about the conflict and develop an improved understanding of the concerns, fears, and needs of affected parties. Dialogue requires participants to suspend attachment to their particular points of views. It stresses respect for others, listening, trust, and the shared pursuit of deeper understanding.

Dialogue helps people to perceive the interconnectedness of the world. Dialogue helps people to transcend their individual perspectives in order to achieve a larger view of reality (O'Sullivan-Lago, and Abreu, 2010). Dialogue requires four basic skills. First, participants must suspend both their attachment to their own positions and their judgments regarding others. This allows participants to be more accepting of other alternate perspectives. It is also key in creating a climate of trust where others will feel free to express their points of view. Second, participants 
must identify their underlying assumptions. Unidentified differences in people's basic assumptions will produce incoherent conclusions. Third, participants must listen actively to each other. Moreover they must remain actively present to each other. Finally, participants must engage in inquiry and reflection, in order to uncover deeper issues and create more profound levels of understanding (Boston Globe 2008). Regular dialogue helps people to identify problems early. Dialogue can lead to a clearer understanding of the problem and help participants to generate a broader set of possible solutions.

Tileagă, (2007), asserts that groups who have practiced dialogue through the earlier stages will be more united behind the final decision, and more committed to it. Dialogue sessions create a safe environment for the expression of differences. The guidelines of dialogue can provide the structure needed for participants to transform chaos into a source of creativity. Dialogue also provides a safe arena in which to express the often turbulent emotions occasioned by the community building process. Finally, dialogue provides a process by which full communities can continue to identify and respond to problems and issues, and so maintain themselves (Tileagă, 2007).

Arbitration is an alternative method to resolve conflicts with one or more arbitrators. It is a more agile way than a judicial process and it is common in commercial contracts which include a clause that states that any problems that may arise between parties in a contract may be solved by arbitration. An arbitration process is a quicker process than a trial (Goldberg, Green and Sander, 1985).

The law provides that the arbitration may be in law, equity or technical. The referees dictate their decision on the basis of their specific knowledge of a particular issue, trade or science (Ogochukwu and Eberinwa 2014). They further added that the parties may agree who will be in charge of the arbitration procedure. Also the parties may freely determine the place of arbitration but usually the arbitration institution decides which will take place. The arbitration process shall not exceed five months duration unless the parties or the arbitrator decide to prolong it. The active role of arbitrators is very important in the arbitration process because they are the ones who carry out the process, determine what evidence will be accepted and valued and at the end they dictate the arbitration award which will end the conflict. The award has the force equivalent to a court order and the parties must comply with it. Arbitrators must meet certain requirements to serve as arbitrators and when they accept their position they assume the obligation to fulfill its function with "dedication and commitment" and as well the responsibility to repair damages caused to third parties by their fault or negligence (Goldberg, Green and Sander, 1985). Before going under an arbitration process it is essential that the parties know about the arbitration clause and also about the arbitration law which will govern the whole process.

\section{THEORETICAL FraMEWORK:-}

The first theoretical construct that this study is premised is social identity theory established by Tajfel and Turner (1979). Social identity theory asserts that group membership creates in-group/self-categorisation and enhancement in ways that favour the in-group at the expense of the out-group. After being categorised of a group membership, individuals seek to achieve positive self-esteem by positively differentiating their group from a comparison outgroup on some valued dimension, Haslam, (2001). In a simplified language, this theory asserts that we must do more than study the psychology of individuals as individuals, but must understand how, when and why individuals define themselves in terms of their group memberships and how these memberships as a consequence affect the behavior of employees within organisations.

The second theoretical framework adopted for this paper is socio-cognitive conflict theory. Socio-cognitive theory (SCT) was developed from social learning theory by Albert Bandura in the 1960s. The unique feature of SCT is the emphasis on social influence and its emphasis on external and internal social reinforcement. SCT considers the unique way in which individuals acquire and maintain behaviour, while also considering the social environment in which individuals perform the behaviour. The theory takes into account a person's past experiences which factor into whether behavioural action will occur. People's past experiences influence reinforcements, expectations and expectancies in specific behaviours and the reason why they engage in such behaviours. Socio-cognitive conflict theory models show how employees react to differences in standards and judgments and how they conform to group opinions.

\section{EMPIRICAL REVIEW:-}

Ada, Adoga and James (2013) conducted a research in College Of Education, Oju, Benue State, Nigeria; on Conflicts as Constraints to Effective Management of Tertiary Institutions in Nigeria. A number of 324 participants 
were chosen, using simple random sampling. They found that conflict is an attendant feature of human interaction in every organisation which cannot be eliminated, therefore, maintaining a cordial relationship between staff, students by school authority, is necessary, they recommended, involving students and trade unions in decision making process which is the most effective way forward for efficient management of tertiary institutions.

The Centre for Effective Dispute Resolution (2005) supports the perception of an increase in organisational conflicts with some hard facts. Their research reported a $17 \%$ increase in organisational conflict measured by more than 115,000 employment tribunal applications in 2004 in the United Kingdom.

Alabi, (2010) conducted a research on Conflict in a Nigeria Universities: causes and effects, using a survey method with 654 participants. The study concluded that there is need for all the groups within the system to recognise potentials and deliberately make concerted efforts to curtail the negative consequences of conflicts. This curtailment could be achieved through meaningful interactions and effective communication; resourcefulness and resource management; and cooperation between the universities and the state. All these measures would culminate in drastic reduction in negative conflict potentials and consequent high goal attainment potential.

A similar research was conducted by Bricoe and Schuler (2004) in Accra, Ghana based on a survey design. Hypothesis was tested using correlation analysis. Bricoe and Schuler found that many institutions use win-lose nature and competitive approach to curb conflict; asserting that such negative view to conflict breed inefficiency, creating destructions. They recommended appropriate guidelines involving cohesion and healthy competition for turning dysfunctional conflicts into functional conflicts which leads to a win-win solution.

\section{Summary Of Literature Review:-}

Summarily, the related literature reviews on this topic, like Ada, Adoga and James (2013) in College Of Education, Oju, Benue State, Nigeria; Alabi (2010) University of Calabar Nigeria and Bricoe and Schuler 2004 Accra Institute of Technology (AIT) Ghana ) all adduced that conflict is often said to be functional for organisations, and all their recommendations still fall within the spectrum of conflict reduction, resolution, or minimization. Meanwhile, their recommendations are usually designed to deal with conflict at group levels and may not be appropriate for macrolevel changes in an organisation. However, these literatures are also deficient in these major areas:

1. There is no clear set of rules to indicate how conflict involving different situations can be managed effectively.

2. There is none that handled conflict in tertiary institutions in Enugu state, Nigeria.

This paper therefore, addresses the lacuna above focusing on tertiary institutions in Enugu state, Nigeria and provides a design for managing interpersonal, intragroup, and intergroup conflicts. Moreover, the study will be useful to the management practitioners as well as the academicians.

\section{RESEARCH METHODOLOGY:- \\ RESEARCH DESIGN:-}

This study adopted a descriptive survey design which aimed at collecting detailed factual information that describes an existing phenomenon.

Population and Sampling Technique:-

The population of this study is made up of employees of three selected universities in Enugu state, Nigeria, which include, University of Nigeria Nsukka, Enugu campus, Enugu State University of Science and Technology, and Institute of Management and Technology, Enugu. A total number of 7,757 of both academics and nonacademic staff of the above tertiary institutions form the population of the study. The composition of population size of the study is represented in table 3.1 below.

Table 3.1:- Tertiary Institutions and Population Size

\begin{tabular}{|l|l|l|}
\hline S/NO & Tertiary Institutions & Population Size \\
\hline 1 & University of Nigeria Nsukka, Enugu campus & 3015 \\
\hline 2 & Enugu State University of Science and Technology & 2795 \\
\hline 3 & Institute of Management and Technology, Enugu & 1947 \\
\hline & Total & $\mathbf{7 7 5 7}$ \\
\hline
\end{tabular}

Source: field work 2015. 


\section{Sample and Sampling Techniques:-}

Non-probability sampling method was employed in selecting the population size of the study. Hence, the random sampling was done using Taro-Yamane arithmetical formula to arrive at sample size "n" with $5 \%$ level of significance.

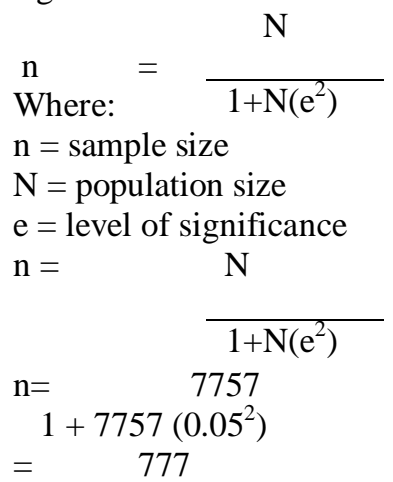

By the above calculations, the sample size is seven hundred and seventy seven (777) which implies that 777 questionnaire was distributed to the above mentioned tertiary institutions. The sample size for each university is determined proportionately by the use of ordinary percentage. The total population of each school is divided by the total sample size and multiplied by 100. Example:

For UNN, $\quad 3015 \times 100 \%$

777

$=\quad 388$

Table 3.2:- Sample size Distribution

\begin{tabular}{|l|l|l|}
\hline S/NO & Respondents & Total \\
\hline 1 & University of Nigeria, Nsukka, Enugu campus & 388 \\
\hline 2 & Enugu State University of Science and Technology & 359 \\
\hline 3 & Institute of Management and Technology, Enugu & 250 \\
\hline & Total & 777 \\
\hline
\end{tabular}

Source: field work 2015.

METHOD OF DATA COLLECTION:-

Data for the research was collected from both primary and secondary sources. The primary data include questionnaire. The questionnaire was structured and the respondents placed on a five point Likert scale as follows; strongly agreed - 5points, Agree-4 points, Undecided - 3points, Disagree - 2points, and Strongly disagree - 1points. The secondary data are information gathered from e-books, textbooks journals and e- magazines. The instrument was validated using content validity. Reliability was tested using test- retest.

Table 3.3:- Reliability Statistics

\begin{tabular}{|l|l|}
\hline Cronbach's Alpha & Number of Items \\
\hline .715 & 10 \\
\hline
\end{tabular}

From the reliability test, the measuring instrument is reliable at alpha value of 0.715 .

DATA PRESENTATION AND ANALYSIS:-

In order to assess the extent to which conflict management through arbitration and dialogue can affect effective academic performances in tertiary institutions, a factor analysis was employed to establish the key factors important in the effective conflict management. Pearson's product moment correlation was used to test the hypotheses.

Table 4.1:- Selected Demographic Characteristics of Respondents and Their Universities

\begin{tabular}{|l|l|l|}
\hline Name of the University & Frequency & Percent \\
\hline $\begin{array}{l}\text { University of Nigeria Nsukka, } \\
\text { Enugu campus }\end{array}$ & & \\
\hline Academics & 288 & 74.23 \\
\hline Non-academics & 200 & 25.77 \\
\hline Total & 388 & $100 \%$ \\
\hline
\end{tabular}




\begin{tabular}{|l|l|l|}
\hline $\begin{array}{l}\text { Enugu State University of Science } \\
\text { and Technology }\end{array}$ & & \\
\hline Academics & 204 & 57.66 \\
\hline Non-academics & 159 & 42.34 \\
\hline Total and & 359 & $100 \%$ \\
\hline $\begin{array}{l}\text { Institute of Management } \\
\text { Technology, Enugu }\end{array}$ & \\
\hline Academics & 155 & 62 \\
\hline Non-academics & 95 & 38 \\
\hline Total & 250 & 100 \\
\hline GRAND TOTAL & 777 & $100 \%$ \\
\hline
\end{tabular}

Source: Field Survey $(2015$

Test of Hypothesis:-

Hypothesis One:-

Ho: Conflict management by arbitration has no significant positive relationship with academic proficiencies of selected tertiary institutions in Enugu state, Nigeria.

Hi: Conflict management by arbitration has a significant positive relationship with academic Proficiencies of selected tertiary institutions in Enugu state, Nigeria.

Table 4.2:- Correlation between Arbitration and Academic Proficiency

\begin{tabular}{|c|l|l|}
\hline & ARBITRATION & ACAD PROFICIENCY \\
\hline ARBITRATION Pearson & 1 & $.445^{*}$ \\
Correlation \\
Sig. (2-tailed) & 1760 & .014 \\
N & & 1760 \\
\hline $\begin{array}{l}\text { ACAD PROFICIENCY Pearson } \\
\text { F Correlation } \\
\text { Sig. (2 tailed) }\end{array}$ & $445^{*}$ & 1 \\
N & 014 & \\
\hline
\end{tabular}

*correlation is significant at the 0.05 level (2-tailed).

This shows that conflict management through arbitration has a significant positive effect on academic proficiency of tertiary institutions in Enugu state since the p-value (0.014) is less than 0.05 (at 2-tailed test) as can be seen in the Table of Pearson correlation above. This implies that conflict management through arbitration has a significant positive relationship with the performance of tertiary institutions in Enugu state.

\section{Hypothesis two:-}

Ho: Dialogue has no significant positive relationship with incessant closure of selected tertiary institutions in Enugu state Nigeria.

Hi: Dialogue has significant positive relationship with incessant closure of selected tertiary institutions in Enugu state Nigeria.

Table 4.3:- Correlation between Dialogue and Incessant Closure

\begin{tabular}{|c|l|l|}
\hline DIALOGUE & DIALOGUE & INCESSANT CLOSURE \\
$\begin{array}{c}\text { Pearson } \\
\text { Correlation }\end{array}$ & 1 & $.657^{* * *}$ \\
Sig. (2-tailed) & 1760 & .000 \\
$\mathrm{~N}$ & $.657^{* *}$ & 1760 \\
\hline $\begin{aligned} \text { INCESSANT CLOSURE Pearson } \\
\text { F Correlation }\end{aligned}$ & 1 \\
Sig. (2 tailed) & .000 & \\
$\mathrm{~N}$ & 1760 & 1760 \\
\hline
\end{tabular}

*correlation is significant at the 0.01 level (2-tailed) 
There is a significant positive relationship between dialogue and incessant closure of tertiary institutions in Enugu state since the p-value of 0.000 is less than 0.01 (at 2-tailed test) as can be seen in table 4.3 of Person correlation above. This implies that dialogue can go a long way in eradicating incessant closure of tertiary institutions in Enugu state.

\section{Summary of Findings, Conclusion and Recommendations:- FINDINGS:-}

From the analysis carried out in this study, the researchers found that effective conflict management through dialogue and arbitration has a significant positive effect on performance of selected tertiary institutions in Enugu state. It shows that the use of dialogue and arbitration in the management of conflict can go a long way in promoting academic proficiency and in eradicating incessant closure of tertiary institutions in Enugu state, Nigeria. It further reveals that for optimal performance of organisations with human elements, the organisation must create conflict management mechanism such as arbitration and dialogue.

\section{Conclusion:-}

In view of the above findings, the study concludes that tertiary institutions can maintain academic proficiency and eradicate incessant closure of universities by managing conflict through arbitration and dialogue. There is no doubt that just as conflicts abound in human beings, so it is in tertiary institutions. The school administrators therefore need managerial expertise and leadership qualities to bring the staff, students and other stake holders together to fight a common course to ensure academic success and eradicate incessant closure of tertiary institutions. This study therefore concludes that dysfunctional conflict should be avoided through arbitration and dialogue.

\section{Recommendations:-}

1. This study recommends that for effective performance, authorities of tertiary institutions should be more democratic and skillful in handling the institution's affairs. The affected parties should be called for dialogue from time to time to curb dysfunctional conflicts.

2. Authorities of tertiary institution should always embark or focus more on preventive strategies in order to reduce crisis rather than corrective measures. Step by step conflict management in tertiary institution requires giving consideration to problem solving techniques along with proper use of authority in the enforcement of collective bargaining process. This requires managerial expertise and leadership qualities.

3. The study recommends the use of arbitration, observance of rules and regulations, proper structuring of institutions, provision of adequate communication networks and encouraging meaningful participation of stake holders in resolving conflicts.

4. Courses on conflict management and resolution, good governance, basic human rights, respect for rule of law and teaching of peaceful coexistence as General Studies (GST) in Nigerian tertiary institutions should be enforced with a view to making Nigerian tertiary institutions as much as possible conflict free and also improve performance generally.

\section{References:-}

1. Ada, Adoga James (2013), Conflicts as Constraints to Effective Management of Tertiary Institutions in Nigeria: The Way Forward Mediterranean Journal of Social Sciences MCSER Publishing, Rome-Italy

2. Adam, K (2013), The Language of Power and the Language of Love: Solving Tough Problems in Practice.

3. Adejuwon, K.D \& Okewale, R.A (2009), "Ethnic Militancy, Insurrections and Democracy in Africa: The Case of Nigeria", Journal of Social and PolicyIssues, Vol. 6, No. 4

4. Adeyemi, T.O, Ekundayo, H.T \& Alonge, H.O (2010), "Managing Students' Crisis in Tertiary Institutions in Nigeria" Journal Of Research in National Development, Vol. 8,No. 1, June.

5. Agbonna, S.A. \& Okafor, I.P. (2008), Perspectives of Nigerian Policemen across Educational Levels on Causes and Prevention of Crime among Nigerian Students", Journal of Arts and SocialSciences, Vol. 10, No. 1

6. Aja, O.J. (2012), Conflicts as a Barrier in Tertiary Institutions for National Transformation. A paper presented at the 31stAnnual national conference of Nigerian association for education administration and planning (NAEAP) October, in Benue Hotels Makurdi.

7. Ajayi, S. (1992), Personnel Management in Nigeria. Lagos: Edition F. Communication.

8. Albert, I.O (2011). Building Peace, Advancing Democracy, Experience with the third party Interventions in Nigeria's conflicts. Ibadan: John Archers publications Ltd. 
9. Alabi, A. T. (2010). Management Information System and Decision-Making in Nigerian Universities. An Unpublished Doctoral Thesis, University of llorin, llorin.

10. Amusan, T. A. (1996). Sources of Conflicts in an Organization. Journal of General Studies in Education,1, (1), 93-99. Charles ,E. Merril.

11. Ayodele, J.B. \& Adewumi, J.O (2007). The Incidence and Management of Conflicts in Secular and NonSecular Tertiary Institutions in South West Nigeria. Educational research and review vol 2 (5).

12. Bricoe, D. R. \& Schuler, R. S. (2004). International Human Resource Management. 2nd Edition. Routledge, London.

13. Deutsch, M. (1973).The Resolution of Conflict. New Haven: C.T. Yale University Press.

14. Ejiogu, A. M. (1990). Educational Management: A System Approach. Lagos: Lantern books.

15. European Journal of Humanities and Social Sciences Vol. 7, No. 1 (Special Issue),

16. Ezegbe C. (1977) The Igbo Ubo-aka: Its Role and Music Among the Nri People: A Thesis (M.Mus) University of British Columbia, 1977 Music Nigerian

17. Fadipe J. O. (2000) Efficiency Indicators For Quality Control on Nigeria. A Journal of NIEPA Ondo

18. Fatile, J.O. \& Adejuwon, K. D. (2011)Conflict and Conflict Management in Tertiary Institutions: The Case of Nigerian Universities. European Journal of Humanities and Social Sciences 7

19. Federal Republic of Nigeria (1981).National Policy on Education Lagos: NERDC.

20. Gerard \& Teurfs (1995) Dialogue and Organizational Transformation, in Community Spirit; Renewing Spirit and Learning in Business, KazimierzGozdz, ed, (san Francisco New Leaders press pp 143-53.

21. Gilhin, C.T. (2004). Conflict Resolution, Negotiation and Team Building. Arts and Contemporary Studies Ryerson University.

22. Goldberg, Eric D. Green, Frank E. (1985), Law 594

23. Haslam, S.A. \& Turner, J.C.. (2001) Social Identity Organizations and Leadershipin M.E. (Ed), Groups at Work: Advances in Theory and Research (pp.25-65). Hillsdale Nj: Eribaum.

24. Kestener, B.P \& Ray, L. (2002). The Conflict Resolution Training Programe Leader's Manual. Jossey-Bass, U.S.A.

25. Mohamedbhai, A. K., Hassan, A. \&Kashif, R. (2009). Impact of Task Conflict on Employee's Performance

26. Ogochukwu, M. Eberinwa (2014) Industrial Relations in a New Era, Out-Right Publishers, Onitsha.

27. O'Sullivan-Lago, R. \& Abreu, G. (2010). Maintaining Continuity in a Cultural Contact Zone: Identification Strategies in the Dialogical Self, Culture \& Psychology, 16, 73-92.

28. Ola, R.F \& Oyibo, E.E (2000), Administrative Theories and Their Applications, Ibadan and Lagos: Amfitop Books.

29. Posigha, B.E \& Oghuvwu, V (2009), "Conflict Among Library Staff in Bayelsa and Delta State of Nigeria", International Journal of Labour and OrganisationalPsychology, Vol. 3, Nos. 1\&2

30. Raudsepp, M. \& Wagner, W. (in press) The Essentially Other: Representational Processes that Divide Groups, in I. Markova, P. Linell, A. Gillespie, G. Hosking, and L. Scarantino (Eds). Trust and Distrust between Groups: Interaction and Representations.

31. Tajfel, H. \& Turner, J. C. (1986) - The Social Identity Theory of Intergroup Behaviour"', in S. Worchel and L. W. Austin (eds) Psychology of Intergroup Relations (pp.7-24), Chicago: Nelson- Hall

32. Tileagă, C. (2007). Ideologies of Moral Exclusion: A Critical Discursive Reframing of Depersonalization, Delegitimization and Dehumanization. British Journal of Social Psychology, 46, 7

33. Uchendu, Anijaobi, \& Odigwe, (2013), Research Journal in Organizational Psychology \& Educational Studies 2(2) 67-71 Emerging Academy Resources (2013) (ISSN: 2276-8475)www.emergingresource.org 